\title{
Poverty Alleviation of Women through Development of Cottage Industry in Cilegon Municipality, Banten
}

\author{
Muslikhin ${ }^{1}$ \\ ${ }^{1}$ Communication Department, Faculty of Economics and Communication, Bina Nusantara \\ University, J1. K. H. Syahdan No. 9, Palmerah, Jakarta Barat 11480 \\ mdmuslihin@gmail.com
}

Received: November $2^{\text {th }}, 2018 /$ Accepted: March $6^{\text {th }}, 2019$

\begin{abstract}
This study aims to describe the implementation of the program of Cottage Industry (Industri Rumahan) in Cilegon Municipalty, Banten. Development of Cottage Industry (IR) is a program initiated by Kementerian Pemberdayaan Perempuan dan Perlindungan Anak (KPPPA). The program will run for three years from 2016 to 2018. For 2016, the program is implemented in 14 districts and municipalities, one of which is Cilegon Municipality, Banten. Data collection is done by interviewing IR perpetrators and assistants. In addition, the data was collected by analyzing the documents such as the records of the implementing team meetings, the companion worker reports, mapping reports and mapping results analysis in the two urban villages that were the locations of IR development implementation. The validity test of data is done by triangulation of source and method.

The study concluded that in general the implementation of IR development program in Cilegon Municipality, namely in Villages Ketileng and Bandengan, has followed the development pattern established by KPPPA. It's just that in some stages is not working properly. The stages that have problems are when determining the number of IR actors who get help and production equipment distribution. Many IR actors protest that they are not included in the IR development program. In addition to the production equipment that is distributed to IR actors, some are not in accordance with their needs so that less than the maximum.
\end{abstract}

\section{INTRODUCTION}

Kementerian Pemberdayaan Perempuan dan Perlindungan Anak (KPPPA) through the Deputy of Gender Equality in 2016, implementing the Cottage Industry Development Program - abbreviated as IR (Industri Rumahan). This program lasts for three years, from 2016 to 2018. IR is a production system which means there is a product produced through the process of forming value-added and certain raw materials, which is done in place of individual houses and not in a special location (factory). The production process utilizes the infrastructure, facilities and other production equipment owned by individuals / groups of joint ventures / cooperatives. Generally, products from home-based industries are handmade, unique in different ways, and often associated with local wisdom and targeted technology (Permen PPPA RI, No. 2, 2016).

IR is classified into three, there are IR Pemula, IR Berkembang and IR Maju. IR Pemula are generally either continuous or consumer based. Capital is still small, according to its own ability is about less than 5 million rupiah. The production process is still simple, and manual. The workforce is still small, about 1-2 people including the owner. IR Berkembang, its production is generally semicontinuous with loose sales. Capital costs between 5- 25 million rupiah and has begun to borrow money from non-formal community financial institutions. The production process started using technology / assisted machine though simple. The workforce is around 3-5 people including the owner. IR Maju production is sustainable or continuous with a particular sales system. Capital range from 25 - 50 million rupiah. Already using a formal financial institution. Its workforce of 6-10 people including owner, and already using high production technology (Permen KPPPA RI , No. 2, 2016). 
In the Implementation Guide for Development Cottage Industry in the Region ( 2016), there are three goals of IR development. First, to increase family income through production activities undertaken at home by entrepreneurial women with the growth of support from husbands and other family members. Second, opens alternative business opportunities. Third, develop creative industries through women empowerment activities in order to strengthen the network of Cottage Industry (p. 5-6)

The IR development program is expected to have a positive effect in ending the 3 negative phenomena in the household, also known as 3Ends, firstly, ending violence against women and children, since the IR development program can be seen as a potential community-based development effort, so it is also expected to provide added value to household income and increase the welfare and welfare of the community-based household. Second is to end human trafficking activities, in various forms, such as sending TKI / TKW abroad. And the third put an end to the economic gap between men and women, so that it will be a big contribution to improving economic resilience of household-based society.

The development of IR is expected to be one of the solutions for unemployment among women as a result of the government's decision to stop and prohibit the placement of Indonesian workers for the category of Domestic Workers or better known as female workers (TKW) in twenty-one Middle Eastern countries, from the beginning May of 2015. National Agency for Placement and Protection of Indonesian Workers (BNP2TKI) data shows a decline in the number of TKW from 2014 until 2016 in line with the termination of TKW shipments abroad. In 2014, the number of TKW working abroad is 246,629 TKW. This number decreased in 2015 to 166,771 TKW. In 2016, the number decreased again to 145,392 TKW http://www.bnp2tki.go.id/uploads/data/data_08-02-2017_111324_DataP2TKI_tahun_2016.pdf.

The IR program is also expected to be a solution for poverty alleviation in the regions, especially among women, especially women who have become heads of households. Data from the Central Bureau of Statistics 2015 or BPS shows that the poverty rate of Indonesia's population is $11.22 \%$ or 28.9 million people. The figures show that the number of poverties in Indonesia is still quite high, and women, being vulnerable and often vulnerable to marginalization. Marginalization of women was reinforced by data support from the National Socio-Economic Survey or SUSENAS one year earlier. In 2014, SUSENAS recorded that $57.76 \%$ of female household heads were only able to buy rice for poor (raskin) for three months, and more in rural areas as much as $73.15 \%$. These female heads of household are generally self-employed or not laborers in a particular person or business organization, amounting to $37.91 \%$. The data show that female heads of self-employed households are more than men who are not laborers in a particular person or business organization, which is only $22.34 \%$ (KPPPA RI, 2016).

As a pilot project, Gender Equality Deputy of KPPPA selected 14 regency and municipality for the location of the IR development program. The fourteen regency and municipality are is the municipality of Cilegon, Banten, Cirebon Regency, West Java, Kendal Regency, Wonosobo Regency, Rembang Regency, in Central Java; Lampung Selatan Regencyt in Lampung; Palembang Municipality, in South Sumatera; Central Bangka Regency, in Bangka Belitung; Central Lombok and, West Manggarai Regency in NTB, West Sumba Daya Regency, in NTT; Landak Regency, in West Kalimantan; Tanah Datar Regency, in West Sumatra, and Ternate Municipality, ini North Maluku. Selection of IR program development pilot locations is based on four reasons, namely high poverty rates and maternal and infant mortality rates; enclave of TKI / TKW; central areas or IR centers; and is part of PATBM (Perlindungan Anak Terpadu Berbasis Masyarakat or Community-Based Integrated Child Protection).

Cilegon municipality was chosen as the location of IR development activities in 2016 due to several reasons. Firstly, Cilegon is one of the areas with poverty rates, high maternal and infant mortality rates. Second, Cilegon is an area of slice or tangent to the activities of integrated community-based child protection programs or PATBM. Third Cilegon is an industrial city, with many industries stands ranging from upstream and downstream industries, which attracts job seekers to come to Cilegon to earn a living. Fourth, the strategic location of Cilegon, located in the Java-Sumatera crossroads, becomes more attractive to job seekers.

In order for the IR development program to proceed as expected, a good and comprehensive program management system is required by carrying out the nine steps of IR development activities, first, Advocacy and drafting the MoU with the district / city government, aiming to build the mayor and regent ( bupati and walikota ) commitment to the implementation of the activities, make work agreements, and division of tasks and obligations in activities; second, the establishment of a regency / municipality executive team based on a mayor /regent decree. The IR program implementing team is 
led by the Chairman of the Regional Development Planning Board or BAPPEDA. The executive team's secretary is the Head of Women's Empowerment, Child Protection and Family Planning (BP3KB). Team members are the Unit of Local Government (SKPD/ Satuan Kerja Perangkat daerah ) and Community Institutions involved in micro business development; third, the preparation of work plans and implementation schedules, starting from resource identification, IR actors mapping, database compilation, intervention design and IR interventions, and national monitoring; fourth, coordination meetings across units of regional apparatus and institutions. The fourth step aims to gain information on programs and activities that can support IR development; Fifth, Identify the resources that can be utilized for IR development, such as capital, financial, marketing, training, assistance, raw materials, business protection, policies, and business development modules (KPPPA RI, 2016).

In general, the five initial steps above can be understood as the process of identifying the potential IR that can be developed by each district / city, and after the five steps are done, then the next step is to perform the action of the IR program, starting from the sixth step, defining locations based on indicators to be able to determine priority locations, including (1) high poverty rates, (2) high number of IR perpetrators,(3) the base areas of TKI / TKW, (4) areas with malnutrition, maternal mortality and infant mortality rate, (5) the areas that have minimal empowerment activities, and (6) the latter are the centers of production. The seventh step is to create a mapping of home industry actors, with the aim of obtaining information about IR actors. Next is the eighth step, which is to make an analysis of mapping results and preparation of intervention design. This eighth step is taken to develop and design the designated interventions, at the individual, group, and community level. The final step is the monitoring, evaluation and preparation of IR progress reports (KPPPA RI, 2017).

In accordance with the joint agreement between the Gender Equality Dept. of KPPPA and the Regency / City Government, the first year program financing shall be charged to the Working Unit of Gender Equality Dept. of KPPPA. The second year, the budget burden is divided into two, namely $40 \%$ charged to the Equalization Work Unit Deputy of KPPPA, and 60\% is charged to the regional income and expenditure budget ( Anggaran Pendapatan dan Belanja Daerah or APBD). Financing of the third year, $20 \%$ is charged to KPPPA and $80 \%$ is charged to APBD.

The focused of this research is how the Municipality of Cilegon implement the IR program management system in accordance with the system established by KPPPA as responsible for the implementation of the IR mining program nationally? What are the obstacles and constraints faced by Cilegon Municipality in implementing IR development in its territory? Cilegon was chosen as a research object because of its location close to Jakarta, where KPPPA office, so assumed the implementation of IR development will run better than other regions. But based on KPPA's evaluation, for the implementation of IR development in 2016, Cilegon is in fact a bad area in implementing IR development. The data is based on the Evaluation of Women Empowerment Activity KPPPA held in Bogor on March 22, 2017.

Research on the role of women in economic life and society is quite a lot. For example, "Village Women Empowerment to Reduce Poverty" by Rosalia Indria Saptaningsih and Tri Siswi Nugrahani published in $2015 \mathrm{http}: / /$ repository.upy.ac.id/339/1/3EK7_Rosalia\%20Indriyati\%20512-524.pdf. Research conducted in Kecamatan Tur, Sleman District, Special District of Yogyakarta concludes that empowerment of village women can bring changes to the group of women to be more developed in order to earn income. The women develop the potential to open a business so that it can form community independence. By empowering women, poverty in the village will be reduced. The next study is about the Role of Women in Poverty Alleviation in Combined Village, Sleman, Special Region of Yogyakarta, by Hastuti published in 2014 https://journal.uny.ac.id/index.php/sosia/article/viewFile/5300/4597. The study concluded that various efforts were made by some village women to escape from the poverty they wound. First, some village women diversify their business. Second, to anticipate family expenditures related to food, clothing and social needs. Third, mobilize all family members to work so that add income. Fourth, owe to fulfill household needs. Fifth, migration to find sources of income elsewhere. Sixth, utilizing families to help alleviate poverty. 


\section{THE METHOD}

This research is qualitative approach with descriptive qualitative methode. Bungin (2011) explains, qualitative descriptive is generally done on case study research, focusing on a particular unit of various phenomena. Qualitative descriptive research is an exploratory research on a social problem or phenomenon ( p.68). Implementation of program development activities of the cottage industry in Cilegon Banten is very interesting to be studied. Its location is close to Jakarta to be an advantage for Cilegon compared to other areas that become pilot projects IR implementation. However, based on the evaluation conducted by KPPPA, the implementation of IR in Cilegon, including the unfavorable process.

The data collection is done by interviewing the perpetrator and companion. In addition, extracting data is done by analyzing documents such as records of meetings of the implementing team, reports of counterpart activities, mapping reports and analysis of mapping results. The validity test of data is done by triangulation of sources and methods.

\section{RESULTS AND DISCUSSIONS MOU and Establishment of Implementation Team}

IR development activities in Cilegon begin with the signing of a joint agreement or MOU between Mayor of Cilegon. H. Tb. Iman Ariyadi with KPPPA Republic of Indonesia represented by Deputy of Gender Equality, dr. Heru Prasetyo Kasidi, M.Sc, at the Office of KPPPA on May 30, 2016. MOU is a form of local government commitment to carry out IR development activities initiated by KPPPA. As follow-up of the MOU, Mayor Cilegon then issued Decree Number 500.05 / Kep.333_BKBPP / 2016 on the Establishment of Implementation Management Team of Cottage Industrial Development, about the composition of the team executors, duties and responsibilities.

The team is headed by the Head of Regional Development Planning Agency Cilegon ( "Badan Perencanaan Pembangunan Daerah or BAPPEDA"). The tasks and responsibilities include guarding and ensuring the development of IRs into the medium-term development plan or RJMD ( "Rencana Jangan Menengah Daerah ") in Cilegon. The Executive Secretary is the Head of the Family Planning Planning Women Protection Agency or BKBPP ( "Badan Keluarga Berencana dan Perlindungan Perempuan" ) whose duties are; socialize on IR development; create a joint work plan at the city level; mapping and arranging IR databases; conducting IR technical activities; report periodically IR implementation to chairman; monitoring and evaluating the implementation of IR development. Members of the implementing team are all units of regional apparatus or agencies in Cilegon Municipality and Community Institutions related to IR development. The duties and responsibilities of members are to support technical activities related to IR development; contribute in accordance with its main duties and functions; reporting on the progress of IR development activities to the Team Leader through the Team Secretary.

Once the implementing teams are established, periodically during June and July, they hold regular coordination meetings to develop work plans and schedule of IR development activities. The coordination meeting was to equate the perceptions of all the stakeholders involved in the development of IRs in Cilegon. The goal is to establish synergy between IR development programs with programs in other agencies existing Cilegon municipal government.

\section{Determination of IR and Mapping Development Pilot Locations}

The implementing team assigned two villages, namely Bendungan and Ketileng, as pilot locations for IR development activities. Determination of the two villages based on input from the Community Empowerment and Food Security Agency or BPMKP ( "Badan Pemberdayaan Masyarakat dan Ketahanan Pangan"), the Industry and Trade Office or the Disperindag ("Dinas Perindustrian dan Perdagangan ")and the Regional Development Planning Agency or "BAPPEDA". Consideration because in two villages, there are many housewives who become IR perpetrators. The location is close to the municipal office making it easier for the process of coaching. The determination of the two villages was then strengthened by the Decree of the Mayor N0.500 / Kep-381-BKBPP / 2016 on Determination of the Location of the Home Industry, on 25 July 2016.

After establishing the IR development site, the implementing team then mapping and analyzing the mapping results to collect data on the existing resources in Ketileng and Bandengan Villages in September and October 2016. Mapping done by survey officer or enumerator came to IR perpetrators 
in two urban villages. Before conducting data collection, enumerators have been given training on filling out questionnaires prepared by KPPPA. The purpose of mapping to obtain information about the identity of business actors, business type, business scale, marketing network, problems encountered, needs ever needed, training already obtained and expected, availability of local raw materials that are easy to use.

From the mapping analysis results inform the number of IR actors in Bendungan and Ketileng Villages, more than 150 people. In the initial stage only 150 IR actors were selected as pilot project consisting of IR Beginner 2, IR Developing 135, and IR Advanced 13 people. This is in accordance with the provisions of the KPPA that for the pilot project only 150 IR actors who will provide intervention in the form of training, assistance and equipment assistance. The type of IR perpetrator business can be grouped into three types: food / food business, handicraft business and sewing / sewing business such as bamboo woven handicraft, and handicraft of motif foam. They opened their initial efforts to help the family economy. The IR investors, $50 \%$ came from their own capital, $30 \%$ came from their own capital assisted by external, and $20 \%$ used their own capital plus loans from formal financial institutions. In addition to the expected training requirements, the results of this mapping show an illustration of the need for production equipment related to the type of IR perpetrator business required and the amount.

\section{Assistance and Training for IR Perpetrators}

After mapping and analysis, in October 2016, field advisors were conducted. In guidance on the implementation of IR development activities, it requires that the implementing team designate field facilitators, whose task is to accompany IR actors since training and equipment assistance. Field adivisor also participate in training provided to IR actors. Other duties of assistants are to provide consultation, assistance during the business development process and facilitate the establishment of non-formal women financial institutions. The chosen field advisor must have integrity and commitment to the development of his village. The selected filed advisor are those who live in Bandengan or Ketileng Villages. (KPPPA. 2017. Petunjuk Pelaksanaan Pendampingan dan pengembangan Industri Rumahan di Daerah)

The executive team appointed Nasrudin and Ujang to become field advisor for IR perpetrators in Bandengan Village. Nasrudin is a garbage manager in one of the residents or "Rukun Warga" in Bendungan Village. Ujang is a teacher in Madrasah Ibtidaiyah or elementery school. For Ketileng Village designated Rusnawati, one of the heads of neighborhood or "Rukun Tetangga", who daily open a business selling pastries at home. Prior to providing assistance to IR actors, field facilitators were given training by KPPPA. Training materials on the mechanism of the mentoring process and what should be done by the assistant during the accompaniment of IR perpetrators.

Companion activities by field advisors to IR perpetrators conducted from October to December 2016, under the supervision of the implementation team of Cilegon Municipality. The mentoring process is carried out by field advisor periodically visiting IR perpetrators at their production sites or places of business to discuss various matters and issues related to the development and operation of the business. Meetings between IR perpetrators and assistants can be in small groups or individuals. When meetings are in small groups, fellow IR perpetrators with accompanying mediation exchange information, share experiences during running a business. During the mentoring process, counterparts noted the progress experienced by IR perpetrators in the field. Note the monthly mentoring process should be submitted to the implementing team for evaluation materials.

Training activities for IR perpetrators conducted November 2016. Training materials tailored to the needs of IR perpetrators as revealed from the results of mapping analysis, namely; culinary training held November 11-16; product design training and business management on Nov. 17-19; training on financial management, marketing and product diversification on 22-24 November; and financial, marketing and packing training on November 28-30. The training place is conducted in a location not far from where IR perpetrator business, such as in sub- districts village office, school building, and district office. Training materials delivered by practitioners or business actors in Cilegon associated with training materials. In addition, the providers of training materials also come from related agencies in Cilegon. This training activity is held / conducted by the Secretary of the implementation team in this case the Head of Family Planning and Women Protection Agency for Women or BKBPP Cilegon. 


\section{Distribution Production Equipment}

Interventions provided by the implementing team to IR perpetrators, in addition to mentoring and training, are the aid of production equipment, not money. With this production equipment, IR perpetrators will be able to produce various types of products in accordance with the type of business, which results are then sold so that profit. In addition, production equipment is the main capital that will be used forever for IR perpetrators to produce. The type of production equipment provided is tailored to the needs of IR perpetrators to be intervened. For example, for crafters the motive of a given aid is a sewing machine. For the snack maker assistance is provided in the form of gas stove or frying pan. What production equipment is needed by the IR perpetrators, all of which have been recorded based on the results of the previous mapping analysis.

Procurement and production equipment production by the executing team is conducted from October to December 2016. Procurement process of production equipment takes a long time, because it concerns the technical administration of procurement of goods services in accordance with the provisions of existing legislation, such as through tender so that time consuming. After the administrative process of procurement of production equipment is completed, followed by the procurement of production equipment and distribution to IR perpetrators. For the distribution of production equipment to IR perpetrators involves a field advisor. Goods are delivered by a field advisor to the location of the IR perpetrator's business.

\section{Evaluation and Monitoring}

The final stage of the implementation of IR development in 2016 is evaluation and monitoring. Evaluation is done both in each stage of activity and overall stages. Evaluation works not only to find out the results of the implementation of joint work programs whether the work is in accordance with the work program established, but also to make adjustments if necessary, in accordance with changes in environmental conditions. Based on the evaluation, a significant stage raises the problem is when mapping and analysis of mapping results to determine the IR perpetrators who will get help. As the number of IR perpetrators in Ketileng and Bandengan Villages is more than 150, while only 150 are provided, there is a problem in determining which IR perpetrators will be included in the IR development program. This brings the effects of envy and anger among other IR perpetrators who do not enter the program. This happens because of the lack of strict enumerators in running the IR criteria set by KPPPA.

\section{Obstacles in Implementation}

The success of IR development is closely related to the behaviour of IRs who receive assistance. The obstacles that arise during the implementation of IR development are the perceptions of IR perpetrators who assume that if there is a program from the government, it means they will receive financial aid. Generally, IR perpetrators expect money aid for capital, so when given the production equipment, they are shocked. Another problem that arises and becomes an obstacle is the determination of the type of equipment given to IR perpetrators. Not a few IR perpetrators who claimed the equipment provided by the implementing team did not suit their needs. This happens because the mapping current is less accurate. Another impediment is the lack of innovation and creativity of products produced by IR perpetrators get into the wider market.

\section{CONCLUSION}

The study concluded that in general the implementation of IR development program in two villages in Cilegon Municipality, namely Ketileng and Bandengan, has followed the development pattern established by KPPPA. It's just that in some stages it is not working properly. The stages that have problems is when determining the number of IR perpetrators who get help and the distribution of equipment. In this stages, there are protests from IR perpetrators who are not included in the program so as to cause jealousy. The reason is because the provisions about the IR perpetrators who are entitled to get help, not run strictly. In addition to tools that are distributed to IR perpetrators, some are not in accordance with their needs so that less than the maximum. 


\section{REFERENCES}

Bungin, Burhan. Ed. 2. . (2011). Penelitian Kualitatif: Komunikasi, Ekonomi, kebijakan Publik, dan Ilmu Sosial. Jakarta: Kencana Prenada Media.

Creswell, John W. Ed-4. Terjemahan.( 2016). Research Design,Pendekatan Metode Kualitatif, Kuantitatif, dan Campura. Yogyakarta: Pustaka Hidayah.

Denzin, Norman K. And Lincoln Yvonna S.( 2009). Terjemahan. Handbook Of Qualitative Research. Yogyakarta: Pustaka Pelajar.

Dilla, Sumadi. (2010 ). Komunikasi Pembangunan, Pendekatan Terpadu. Bandung: Remaja Rosdakarya

Jellineck, Lea. 1995. Seperti Roda Berputar, Perubahan Sosial Sebuah Kampung di Jakarta. Jakarta: LP3ES.

Moleong, Lexy J. (2007). Metodologi Penelitian Kualitatif. Bandung: PT. RemajaRosdakarya.

\section{Another references}

Kementerian Pemberdayaan Perempuan dan Perlindungan Anak RI. 2016. Laporan Akhir Kegiatan Pemberdayaan Perempuan Melalui Pengembangan Pelaku Industri Rumahan 2016 (Ringkasan). Jakarta: KPPPA RI

Kementerian Pemberdayaan Perempuan dan Perlindungan Anak RI. 2017.Petunjuk Pelaksanaan Pengembangan Industri Rumahan Di Daerah. Jakarta: KPPPA RI

Kementerian Pemberdayaan Perempuan dan Perlindungan Anak RI. 2017. Petunjuk Pelaksanaan Pendampingan dan Pengembangan Industri Rumahan di Daerah. Jakarta: KPPPA RI

Peraturan Menteri Pemberdayaan Perempuan Dan Perlindungan Anak. Nomor 2 Tahun 2016. Tentang: Pedoman Umum Pembangunan Industri Rumahan Untuk Meningkatkan Kesejahteraan Keluarga Melalui Pemberdayaan Perempuan. Jakarta: KPPPA RI

Pemerintah Daerah Kota Cilegon. 2016. Laporan Pemetaan Industri Rumahan Kota Cilegon 2016. Banten: Pemkot Cilegon.

Pemerintah Daerah Kota Cilegon. 2016. Laporan Analisis Hasil Pemetaan Industri Rumahan Kota Cilegon 2016. Banten: Pemkot Cilegon

Pemerintah Daerah Kota Cilegon. 2016. Laporan Kegiatan Pendamping IR 2016. Banten: Pemkot Cilegon.

Website:

Retrieved August 2, 2017, from http://www.bnp2tki.go.id/uploads/data/data 08-022017 111324_Data- P2TKI tahun_2016.pdf.

Retrieved August 15, 2017,from http://repository.upy.ac.id/339/1/3EK7_Rosalia\%20Indriyati\%

Retrieved August 15, 2017,from https://journal.uny.ac.id/index.php/sosia/article/viewFile/5300/4597. 